\title{
Review
}

\section{How to Fulfill Carotenoid Needs during Pregnancy and for the Growth and Development of Infants and Children - A Review}

\author{
Monika Nur Utami Prihastyanti, Rosita Dwi Chandra, Diah Mustika Lukitasari \\ Ma Chung Research Center for Photosynthetic Pigments, Universitas Ma Chung, Villa Puncak Tidar N-01, Malang, East Java 65151, Indonesia
}

\section{ARTICLE INFO}

\section{Article History}

Received 26 February 2021

Accepted 15 June 2021

Keywords

Carotenoids

pregnancy

growth and development

carotenoid-rich foods

\begin{abstract}
Society's latest lifestyle has developed to a more rapid mobilization and advanced technology which makes people's daily needs of nutrients have altered as well. This phenomenon comes to consequences where healthy diet has been neglected and people consume food only to fulfill the calories-which can be supplied by consumption of macronutrients such as carbohydrates, proteins, and fats. To reach good health status, intake of micronutrients is also important to maintain biological process occurred inside human's body as the deficiency of them may interfere the continuity of metabolic regulation of the body. Carotenoids have been known as pigments that are synthesized only in plants. The roles of carotenoids for the improvement of health have been investigated by numerous research reports, and they are highlighted in this review paper, especially their role for pregnancy and also, growth and development of infants and children. Readers will be able to read recommendation of carotenoid sources and their carotenoid composition that can be consumed periodically. Furthermore, several techniques on processing technology were also elaborated to improve people's knowledge to preserve carotenoids in the ingredients.
\end{abstract}

\section{GRAPHICAL ABSTRACT}

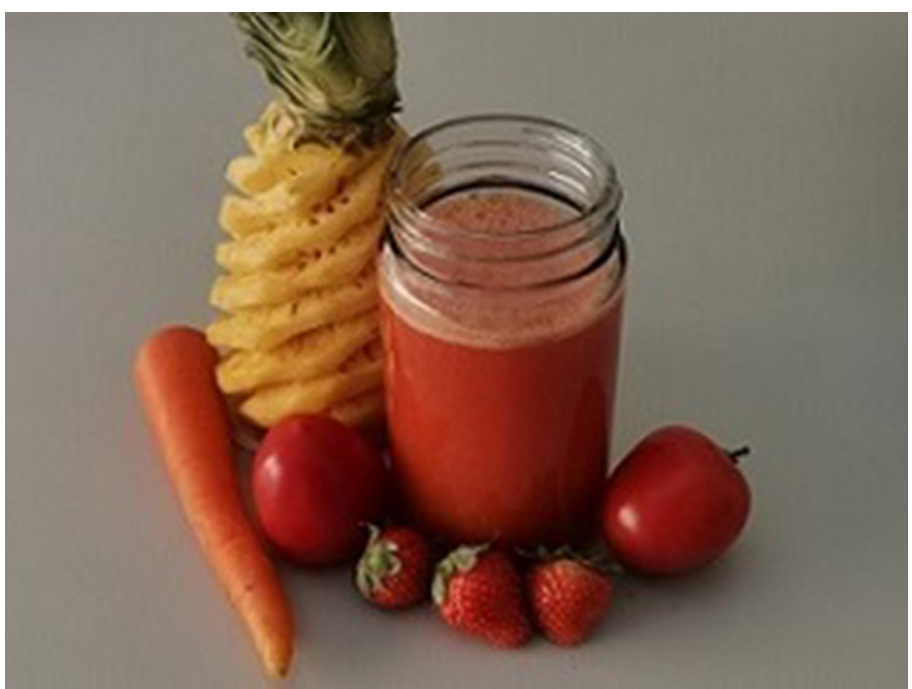

(C) 2021 The Authors. Publishing services by Atlantis Press International B.V. This is an open access article distributed under the CC BY-NC 4.0 license (http://creativecommons.org/licenses/by-nc/4.0/).

\section{INTRODUCTION}

Changes in way of living practice in recent years have drawn large number of people to be more rapidly mobile, technologydependent, and have fast-paced lifestyle which resulted in the transformation of food consumption. Energy-dense foods have become

“Corresponding author. Email: monika.nur@machung.ac.id

Peer review under responsibility of the International Association of Dietetic Nutrition and Safety popular lately, especially upon the emerging fast-food franchise all over the world. Fast-food, such as hamburgers, french fries, pizza, and soda, are generally acknowledged as energy-dense foods, yet having low nutrient content [1]. In parallel, the development of online food service application has enabled people to get their food easily. It is convenient for people to experience this online service because it reduces the time and labour of food preparation and cleaning that follows [2]. Survey released by Chenzi Technology in China revealed that the number of takeaway consumer in China has grown from 256 million in 2016 to 421 million in 2019 [3]. 
In South-East Asia, although Western-style and franchise fast foods are considered as snacks that are not consumed periodically, people in several in region of Malaysia, Philippines and Indonesia have added more sugar and oil to their daily meal recipes [4]. Study in Indonesia by Blum et al. [5] and Green et al. [6] shows that children are most likely to consume snack foods that contain uncontrollable calories (mostly from sugar, salt and fat) than healthy foods with proper nutrition value, thus, could lead to micronutrient deficiency which is one of the important issue that Indonesia households have faced. This poor dietary pattern has come to a consequence that people nowadays consuming more macronutrient and having low micronutrient intake, thus, has led to arising of health issue. Lack micronutrient intake can lead to micronutrient deficiencies which can affect cognitive function and physical performance on children and induce complications during pregnancy $[7,8]$. Pregnant woman and children under 5 years old are at high risk of micronutrient deficiencies.

Required in trace amounts, carotenoids which are abundantly found in fruits and vegetables are considered as important micronutrient that contribute to health. Until 2018, approximately 850 types of carotenoids have been identified and widely distributed in photosynthetic bacteria, some species of archaea, fungi, algae, plants and animals. The basic structure of carotenoids consists of a polyene chain with nine conjugated double bonds and end group at both ends of the polyene chain. There are two major groups of carotenoids. The first group is hydrocarbon carotenoids-commonly called carotenes. $\beta$-carotene is the most wellknown member of this group (Figure 1). The other group is called xantophylls which contain oxygen functions in the structure. $\beta$-cryptoxanthin, lutein, and zeaxanthin are example of carotenoids which belong to xantophylls $[9,10] . \alpha$ - and $\beta$-carotene are important source for vitamin A. As Vitamin A Deficiency (VAD) affected approximately 190 million preschool children and 19.1 million pregnant women worldwide [11], the fulfillment of $\alpha$ and $\beta$-carotene consumption may reduce the risk of VAD. Other members of carotenoids such as lycopene, lutein and zeaxanthin, have been linked to improve biological functions and reduce the risk of several non-communicable diseases due to their antioxidant activity and photoprotective properties [12]. The roles of carotenoids as antioxidant to enhance health function have been investigated through several research. Lycopene, which has been known as the predominant carotenoids found in tomatoes, was effective to inhibit smoke-induced oxidative stress. Thus, the administration of lycopene could be used as feasible means to prevent oxidative stress which can trigger lung cancer [13]. Lutein signified protective action for retinal pigment epithelium cells in macular tissue against oxidative stress [14]. High intake of $\alpha$ - and $\beta$-carotene-rich foods was associated with low risk of cardiovascular disease [15]. Astaxanthin, known as having the highest antioxidant activity, plays an important role in managing the risk of artherosclerosis by reduction of inflammation and modification of blood levels in Low-Density Lipoprotein (LDL) and High-Density

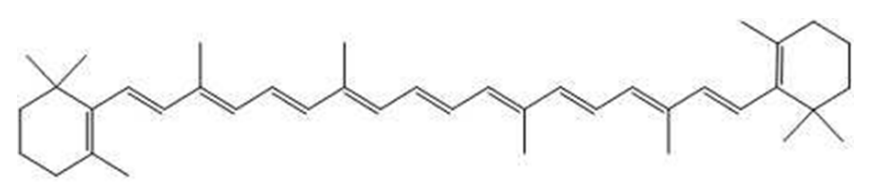

Figure 1 Structure of $\beta$-carotene.
Lipoprotein (HDL) [16]. Thus, consumption of carotenoid-rich ingredients may lower the risk of catching degenerative diseases.

Carotenoids are exclusively synthesized in plants and responsible for pigmentation [17]. Carotenoids act as accessory pigments to chlorophylls in light-harvesting process. Absorbing light in the visible region at 400-500 $\mathrm{nm}$, carotenoids, therefore, bring out yellow, orange and red color. The conformation of carotenoid structure was designed to be fit into the cellular system in order to function effectively inside human body [9]. Moreover, the conjugated $\mathrm{C}=\mathrm{C}$ double bonds of carotenoid corresponds to its antioxidant properties as they are capable to interact with singlet oxygen, which can be oxidative toward cellular substances once it is generated [18]. Carotenoids possess quenching ability against singlet oxygen which could produce carotenoid triplet state. Longer chain carotenoids show higher quenching rate constants, in fact, carotenoids such as decapreno- $\beta$-carotene and dodecapreno- $\beta$-carotene have double quenching rates than that of $\mathrm{C}_{40}$ carotenoids. On the other hand, shorter chain carotenoids exhibit slower quenching rates. For example, the quenching rate of lutein (with 10 double bonds) is half that of $\beta$-carotene. The presence of xantophyll carotenoids enables electron transfer reaction from the radical species to carotenoids' functional groups through several mechanisms, i.e. by abstraction of an electron from carotenoid by free radicals generating carotenoid radical cation $\left(\mathrm{CAR}^{\bullet+}, 1\right)$, by addition of the solvated electron to the carotenoids producing radical anions $\left(\mathrm{CAR}^{\bullet-}, 2\right)$, by the generation of neutral carotenoid radical $\left(\mathrm{CAR}^{\bullet}, 3\right)$ from the loss from $\beta$-carotene radical, and by hydrogen abstraction from a carotenoid to a free radical which then generates carotenoid neutral radical $[19,20]$.

$$
\begin{aligned}
& \mathrm{CAR}+\mathrm{R}^{\bullet} \rightarrow \mathrm{CAR}^{\bullet+}+\mathrm{R}^{-} \\
& \mathrm{CAR}+\mathrm{e}^{-} \rightarrow \mathrm{CAR}^{\bullet-} \\
& \mathrm{HCAR}^{\bullet+} \rightarrow \mathrm{CAR}^{\bullet}+\mathrm{H}^{+} \\
& \mathrm{HCAR} \rightarrow \mathrm{CAR}^{\bullet}+\mathrm{H}^{\bullet} \\
& \mathrm{HCAR}^{\bullet+} \rightarrow \mathrm{CAR}^{\bullet}+\mathrm{H}^{+}
\end{aligned}
$$

Based on the above-mentioned mechanisms, the fulfillment of carotenoid needs becomes extremely important. Several countries in South-East Asia have conducted fortification program to alleviate the number of micronutrient deficiencies. For instance, the needs of vitamin A can be fulfilled by consuming provitamin A carotenoids, such as $\alpha$-carotene, $\beta$-carotene and $\beta$-cryptoxanthin. Several efforts to combat vitamin A deficiency have been made. Fortification of vitamin A has been performed in Malaysia for milk (condensed, evaporated and filled). In the Philippines, the same regulation has been applied for wheat flour, refined sugar and cooking oil. Similar policy has been implemented in Thailand for condensed milk and margarine and in Indonesia for cooking oil. Unfortunately, to execute the fortification policy, a synthetic compound has been used-for example, synthetic retinyl palmitate or retinyl acetate in the case of vitamin A fortification [20,21]. On the other hand, plentiful of natural ingredients around us contain carotenoids, including provitamin A carotenoids, which we can consume directy or after processing. Considering the importance of carotenoids, thorough explanation on the pigment function to improve health should be elaborated. Therefore, this article will elaborate the health effect of carotenoid-rich diet, how carotenoids 
could minimize the health damage, where we can find carotenoids from natural resources and how we can perform food processing to minimize the damage of the pigment itself to gain optimum function of carotenoids to our body.

\section{CAROTENOID ROLE FOR GROWTH AND DEVELOPMENT}

The importance of antioxidant starts since the early life because oxidative stress has become a silent threat for pregnancy health as it may be the cause of some interferences. The role of placenta is essential since it is the organ where interaction between the fetus and the mother takes place [22]. At the beginning of pregnancy, the development of healthy placenta involves the production of Reactive Oxygen Species (ROS) because it is needed in a low level for cell proliferation and palcental angiogenesis. At the same time, antioxidant protection increases to protect the embryo from damage induced by ROS $[23,24]$. As the placenta becomes perfectly developed to support maternal circulation, the level of ROS may raise as the result of increasing oxygen intake, thus, also increase the risk of oxidative stress which could endanger the mother and the fetus $[23,25,26]$. Moreover, placenta is recognized as having high content of polyunsaturated fatty acids, making it vulnerable to lipid peroxidation [27]. As the result, several interferences during pregnancy have been associated to oxidative stress. Getastional Diabetes Mellitus (GDM), pre-eclamspia and Intrauterine Growth Restriction (IUGR) are among the most common disorders related to oxidative stress during pregnancy. The antioxidant activity of carotenoids may reduce the odds of the interefences during pregnancy.

Getastional Diabetes Mellitus is the condition of having high level of glucose in blood that is observed during pregnancy. This condition occurs because the hormones produced by placenta, such as cortisol and oestrogen, interfere the utilization of insulin. The effect culminates during the 26th to 33rd week of pregnancy $[28,29]$. According to data presented by Nguyen et al. [30], the prevalence of GDM in Eastern and Southeast Asia was 10.07\% despite substantial variations across nations. In other words, approximately one in 10 pregnant women in Eastern and Southeastern Asia suffered from GDM [30]. The effect of oxidative stress to pregnancy with gestational diabetes can be worse because of vascular disfunction that may follow [31]. Hence, Lorenzoni et al. [31] performed investigation aiming at observing the antioxidant protective role on GDM by administration of $10 \mathrm{mg}$ lutein and $2 \mathrm{mg}$ zeaxanthin. The oxidative stress was determined by measuring Total Hydroperoxides (TH) from the blood of the subjects. The obtained data suggested that $\mathrm{TH}$ value of pregnant women supplemented with the carotenoids was $605 \mathrm{CU}$, while that on unsupplemented women was 695.2 CU. Furthermore, evidence also showed that newborn babies from pregnant mothers with GDM who were administered with the carotenoids exhibited significantly lower $\mathrm{TH}$ values compared to those from mothers who were not [31].

Study cases reported by Kramer et al. [32] in Canada suggested that low concentration of carotenoids ( $\alpha$-carotene, $\beta$-carotene, $\alpha$-cryptoxanthin, $\beta$-cryptoxanthin, and lycopene) were found in preterm birth, thus, the experiment which associated the low carotenoids with the risk of preterm birth was conducted. The result suggested that high plasma concentrations of $\alpha$ - and $\beta$-carotene, $\alpha$-and $\beta$-cryptoxanthin, and lycopene were associated with reduced risk of spontaneous preterm birth [32]. A study by Carmichael et al. [33] investigated the implication of carotenoids diet on the risk of preterm birth. The obtained data revealed that low intakes of $\beta$-carotene and zinc were associated with increased risk of deliveries before 32 weeks, and that of $\alpha$-carotene increased the risk of deliveries at 35-36 weeks. On the other hand, decreased risk of deliveries at 32-34 weeks was observed in subjects with high intakes of $\alpha$-carotene and magnesium. This result suggests that the possibility of having preterm deliveries can be reduced by having high intke of carotenoids which can be obtained from food or supplements. Accordingly, preterm infants should be fed with proper amount of carotenoids. Breast milk is always the best choice to feed infants because it contains various carotenoids. Based on the finding of Khachik et al. [34], by means of high-performance liquid chromatography and mass spectromery, 34 carotenoids have been found in human breast milk and serum of lactating mother. $\alpha$-Carotene, $\beta$-carotene, $\beta$-cryptoxanthin, lycopene, lutein, and zeaxanthin were among the 34 identified carotenoids. Moreover, formula supplemented with additional carotenoids could be alternative to fulfill the needs of carotenoids in preterm infants [34]. Lower concentration of lutein and zeaxanthin were discovered in brain tissue of preterm infants [35], therefore, the administration of carotenoids to preterm infants would also improve the needs of carotenoids especially for their growth and development.

Pre-eclampsia is another interference in pregnancy caused by lipid peroxidation as the result of free radicals action which then results in vascular endothelial damage [36]. Pre-eclampsia is characterized by the onset of hypertension and proteinuria after 20 weeks' gestation [37]. Administration of lycopene was proven to reduce the risk of pre-eclampsia in primigravida women. Study by Sharma et al. [36] on primigravida women reported that out of 135 patients who were not administered with lycopene, there were 24 patients developed pre-eclampsia (17.7\%). Meanwhile, out of 116 patients who were given lycopene supplement, only $8.6 \%$ (10 patients) developed pre-eclampsia. Overall, a reduction by $51.4 \%$ in pre-eclampsia incidence was observed upon the supplementation of lycopene [36]. Another interference in infant growth known as IUGR can occur during pregnancy as the result of lack of antioxidant capacity leading to oxidative stress, and consequently, the babies are born with Small for Gestational Age (SGA). Proper intake or administration of carotenoid increased its concentration in the plasma, thus, helped reducing the occurrence risk of SGA [38]. Studies also show that low level of carotenoids was found in the mothers giving birth to babies with IUGR $[35,36,39]$.

The important role of carotenoids for health continues to the growth and development of fetus, infants and children. Several carotenoids, such as lutein, zeaxanthin and meso-zeaxanthin are important in fetal growth especially for macular and brain development. In macular tissue, those pigments are found especially accumulated in fovea and retina [39-42]. Lutein and zeaxanthin contribute in oxygen utilization from fovea $[43,44]$. They also improve visual function by enhancement of scoptopic noise and light scatter [45]. Recently, children have been exposed with technology devices (smartphone, laptop, tablet, smart TV, etc.) since young age. The exposure of high light intensity from the devices could result in degradation of visual function due to photodamage caused by blue light illuminated from the devices [46]. In long term, the visual degradation is often associated with Age-related 
Macular Disease (AMD). The damaging effect of blue wavelength may be prevented by the protective action from lutein in the retina which acts as acceptor of free oxygen radicals [47]. Moreover, other compound which is important in visual function is retinol. As a matter of fact, Chan et al. [48] reported that retinol concentrations in subretinal fluid was $166 \mathrm{ng} / \mathrm{mL}$, which was higher than lutein $(41.4 \mathrm{ng} / \mathrm{mL}$ ) [48]. Retinol (in form of all-trans-retinol) is known to be able to mediate photooxidative damage by several mechanisms, i.e. generating singlet oxygen, and oxidizing protein, lipids, and DNA [49]. Other carotenoids, i.e. $\alpha$ - and $\beta$-carotene, consist of retinyl group which can be converted into retinol. They act as precursor of vitamin A which is essential for human visual function. Evidence shows that supplementation of $\beta$-carotene together with vitamin $\mathrm{C}$ and $\mathrm{E}$, zinc and copper reduced the risk of AMD [50-52].

The function of carotenoids is great benefit for cognitive development due to its activity in brain tissue. Lutein contributes to the myelination in the white matter which primarily continues to grow during the first 2 years of life [53]. Lutein also helps development of visual cortex in humans [54,55]. Determination of carotenoids from brain tissue which was extracted from hippocampus, prefrontal, frontal, auitory and occipital cortices of deceased infants suggested that several carotenoids have been found, i.e. lutein (range 0-181.7 pmol/g), zeaxanthin (range 0-33.94 pmol/g), cryptoxanthin (range $0-35.29 \mathrm{pmol} / \mathrm{g}$ ) and $\beta$-carotene (range 0-88.19 $\mathrm{pmol} / \mathrm{g}$ ). Lutein was known to be the predominant pigment found in brain tissue as the mean concentration of lutein was $>40 \mathrm{pmol} / \mathrm{g}$, while that of other pigments combined was $\leq 40 \mathrm{pmol} / \mathrm{g}$ [35]. In fact, the amount of lutein was found more than half of total carotenoids in brain tissue.

The presence of lutein and zeaxanthin as macular pigments was linked to cognitive function based on cognitive assesment [56]. The assesment was conducted to evaluate children participants by means of the standard scores for the Woodcock-Johnson III (WJIII) Test of Cognitive Abilities in which participants were instructed to complete series of subtests, i.e. Verbal Comprehension, Concept Formation, Visual Matching 2, Numbers Reversed, Decision Speed, Planning, and Pair Cancellation. The scores generated from the subtests were used to measure Brief Intelectual Ability (BIA), Processing Speed, Cognitive Efficiency and Executive Processes. The result showed that the amount of lutein and zeaxanthin as macular pigments was related to BIA, executive functioning, visuo-spatial thinking abilities, and cognitive efficiency abilities in preadolescent children. As these events occurred in frontal, parietal and occipital cortices of the brain [57], the presence of lutein and zeaxanthin became extremely important for the well-developed cognitive function especially in children. Otherwise, the body and brain cannot function properly.

\section{HOW TO FULFILL CAROTENOID NEEDS}

Nowadays, people's ways of living determine their health status. In urban areas-especially in big cities-where numerous people work intensively, demand of energy-densed and animal-based foods could be higher than in rural areas. The calory intake may be fulfilled by the food due to carbohydrate, fat and sugar content, however, the nutritive value is no longer taken into account. Consumption of carotenoid-rich foods would be helpful to improve people's health issue addressed in the previous section. Although supplementation and fortification program have been successful to suppress the number of child mortality and morbidity [58], people can still perform food-based approach for their daily consumption to fulfill the requirement of both calories and micronutrients.

Proper dietary intake for infants, toddlers and children should be well fulfilled with the right amount and sources of macro and micronutrients. Macronutrients such as carbohydrates, proteins and fats are required to improve growth and development, and they can be found in many varieties of foods, such as in grains, legumes, cereals and animal-based foods. Carbohydrate as the main energy source, can be found in cereals and grains. Inside the body, carbohydrate serve as precursors in synthetic processes [59]. Animal- and plant-based foods, such as fish, meat, poultries, dairy, legumes, grains, nuts, are good source for protein as it is essential to support functional roles in humans' body such as the generation of enzymes, protein transport and hormones [60]. Functioning as the component of cell membrane, brain and nervous system development, fatty acids are important in tissue formation and brain development [61]. Animal-based foods are the most common food source for fatty acids, however, they can also be found in fruits and nuts.

On the other hand, micronutrients, including carotenoids, are abundantly found in fruits and vegetables. The level of each pigments varies in the commodities. Table 1 summarizes the composition of carotenoids from selected fruits, vegetables, and animal-based foods that are commonly consumed. $\beta$-Carotene becomes the most common carotenoids found in the selected fruits. $\beta$-Cryptoxanhin, lycopene and lutein are also found in most fruits and only several contain $\alpha$-carotene, zeaxanthin and violaxanthin. Leafy, non-leafy and rooted vegetables are good source of carotenoids as well. $\beta$-Carotene and lutein can be easily found in most selected vegetables. Lycopene and zeaxanthin are the dominant pigments found in tomato and corn, respectively. The other carotenoids, such as $\alpha$-carotene and $\beta$-cryptoxanthin, are found in several vegetables. The golden rice, is known for its high $\beta$-carotene content, thus, could be used as an effective source of vitamin, especially for Asians who consume rice as the main meal.

In animal-based products, carotenoids are found as lutein in egg yolk which is the result of the pigmentation from the poultry feed. The presence of lutein in egg yolk could improve its oxidative stability against lipid oxidation during storage. Carotenoid is served as astaxanthin and cantaxanthin in sea food such as crustaceans and salmon. Since animals are not able to synthesize carotenoids, the carotenoids in above-mentioned animal-based foods come from their feed. Lutein in egg yolk is originated from grass, maize, other high-carotenoid diets, or purposedly added to their feed. As the feed in the ocean, custacean zooplankton and algae provide astaxanthin to be digested by curstaceans and salmons [62].

Aside from plant- and animal-based foods, breastmilk could also be considered as source of carotenoids especially for infants. Breastfeeding is important phase for infants because they can only fulfill their nutrient from milk, exceedingly during their early stage of life. According to Xue et al. [63], colostrum, which is the first milk secretion postpartum, contained the highest carotenoid level. The concentration of several investigated carotenoids from breast milk produced within $0-4$ days after delivery, i.e. $\beta$-carotene, $\beta$-cryptoxanthin, lutein, lycopene and zeaxanthin, were 8.0, 6.2, 


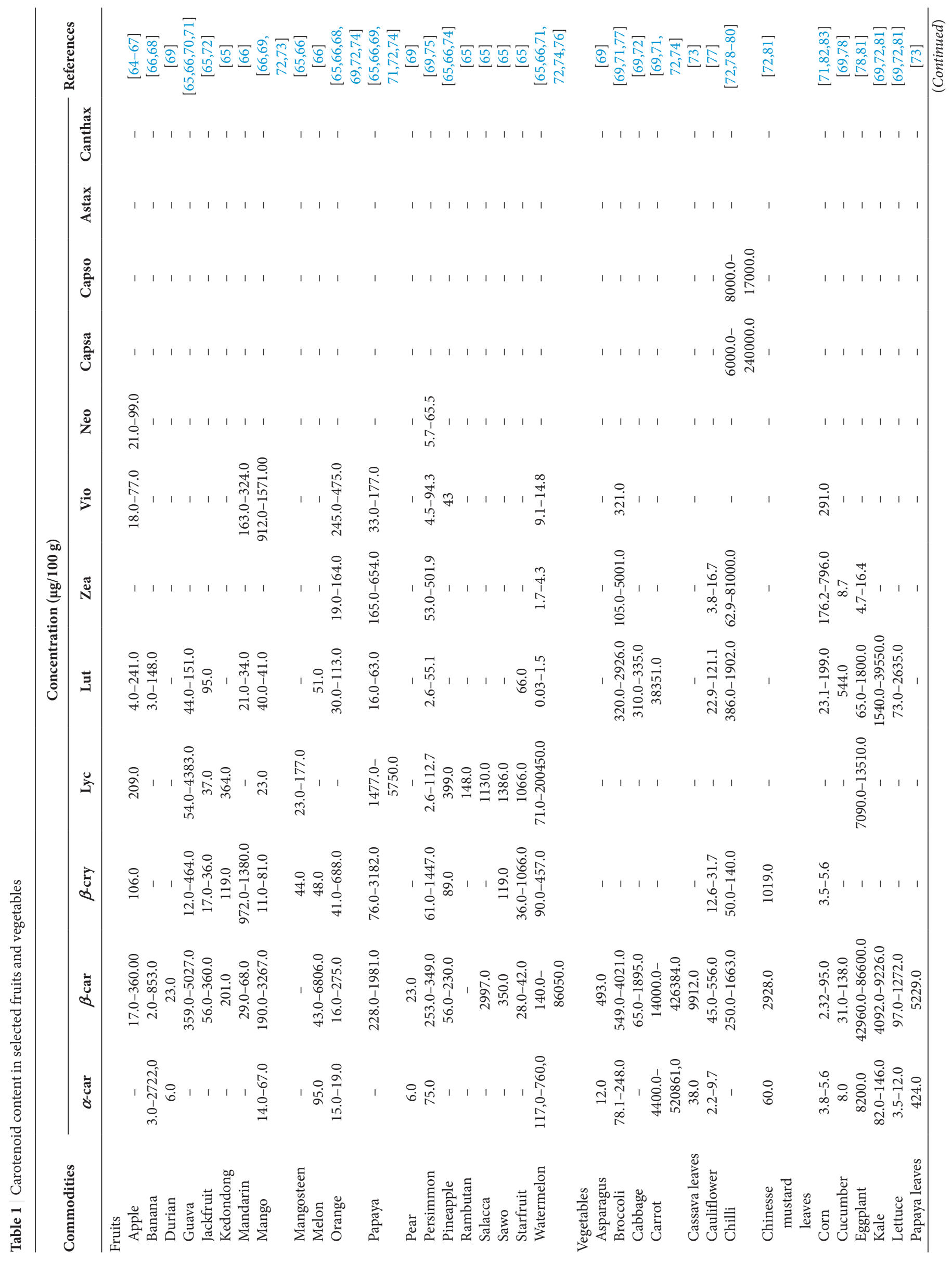




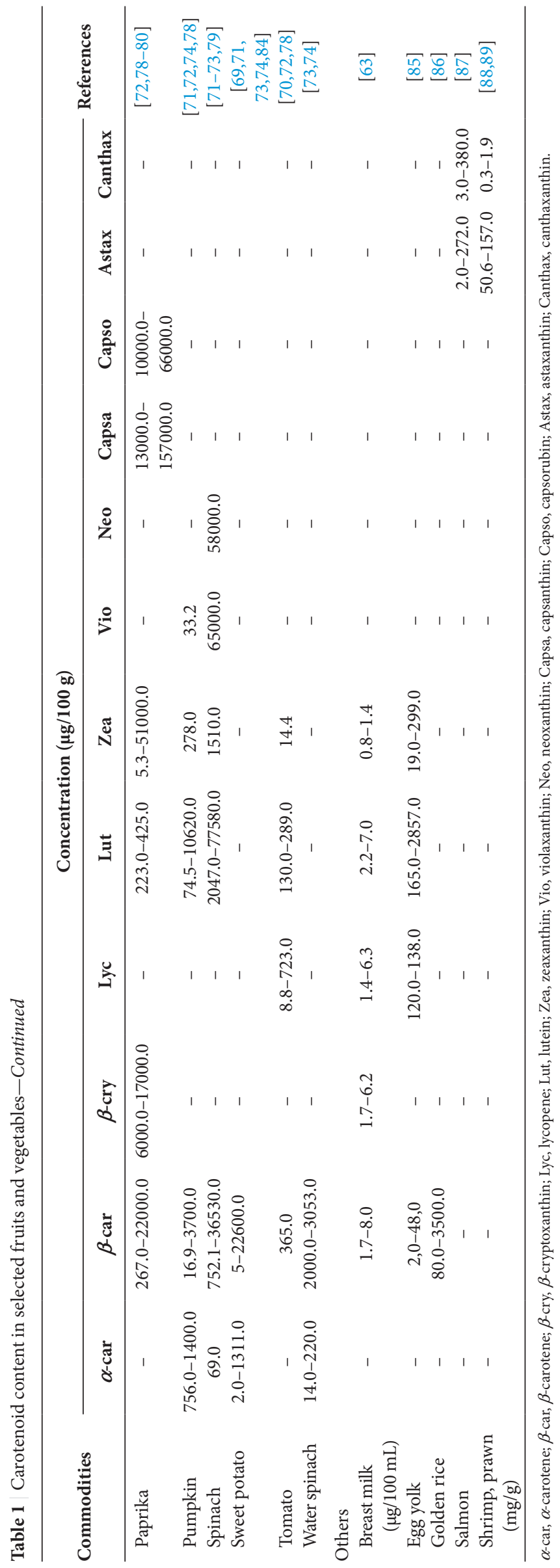

5.7, 6.3 and $1.0 \mu \mathrm{g} / 100 \mathrm{~mL}$, respectively. During days $5-11$, the concentration of $\beta$-carotene, $\beta$-cryptoxanthin and lycopene decreased to $2.8,3.4$ and $2.5 \mu \mathrm{g} / 100 \mathrm{~mL}$, respectively. Increased level of lutein $(7.0 \mu \mathrm{g} / 100 \mathrm{~mL})$ and zeaxanthin $(1.4 \mu \mathrm{g} / 100 \mathrm{~mL})$ was observed during this time. However, the total concentration of those carotenoids decreased during days 5-11. The concentration of carotenoid in the breast milk slowly declined until reaching a stable level after 12 days postpartum. Nonetheless, the composition and concentration of carotenoids in breast milk depend on the carotenoid consumption or supplementation received by the mother. Thus, lactating mothers should be aware to consume healthy ingredients in order to produced nutritious breastmilk.

\section{FOOD PROCESSING TECHNIQUE TO SUPPRESS CAROTENOID DEGRADATION}

Knowledge on how to process food with minimum degradation on the carotenoids content would be important in order to preserve the pigment, thus, giving people the health benefit. Application of heat becomes the most popular method of cooking to prepare meal. Boiling, stir- and deep-frying are common methods of meal preparation. Bakeries and pastries are served through baking process. As pigments are susceptible to heat exposure, the cooking process should be taken into account.

In bakery or pastry production, baking process contributes in carotenoid degradation. The heat generated from the baking process initiated isomerization of all-trans- $\beta$-carotene into the cis-isomers and decreased the retinol equivalents, causing the product having lower vitamin A activity. All-trans-lutein was also altered to cis-lutein, while zeaxanthin remained relatively stable. Interestingly, the dough preparation induced the most damaging effect on the total carotenoid by an average of $61.5 \%$. During storage for $24 \mathrm{~h}$ after the bakery products were baked, approximately only $25 \%$ were retained in the products $[90,91]$.

Kao et al. [92] investigated how cooking method affected carotenoid content (especially lutein, zeaxanthin and $\beta$-carotene) and total carotenoid in vegetables by boiling $(1 \mathrm{~min})$, stir-frying $\left(190^{\circ} \mathrm{C}, 1 \mathrm{~min}\right)$ and deep-frying $\left(190^{\circ} \mathrm{C}, 2 \mathrm{~s}\right)$. The result strongly suggested that boiling preserved the total carotenoid in the vegetables and there were no significant decrease discovered in all-transisomers of $\beta$-carotene, lutein and zeaxanthin. On the contrary, stir- and deep-frying caused major loss of all-trans-isomers of carotenoids. Furthermore, carotenoid composition in the fried vegetables decreased for $9-37 \%$ from the initial concentration with $\beta$-carotene being the most vulnerable pigment toward heat exposure from the cooking methods. The duration of heat exposure was also important factor to determine the pigment stability. Eventhough boiling seemed to have minimum damage to carotenoids, longer boiling time would affect the pigment eventually. At first, heat would damage the carotenoid-pigment complexes, thus, leading to increase in carotenoid concentration. Once the carotenoid was released from the complexed and started to be exposed by heat, the concentration decreased as the duration increased. Hence, brief cooking (approximately $5 \mathrm{~min}$ ) to preserve all beneficial nutrients in vegetables was suggested [92].

The best way to consume carotenoids from fruits is to consume them directly or in form of juices because the degradation is still minimum. Nonetheless, the content could decrease 
due to oxidation during processing or storage. Juice extraction method affects the quality of fruit juice products in terms of phytochemical content and antioxidant properties. For instance, a study by Pyo et al. [93] on apple, pear and mandarin orange juices extracted with juicer was shown to have higher ascorbic acid. Another research by Kim et al. [94] revealed that by means of Low-Speed Mastication (LSM) juicer, tomato juice generated higher lycopene content $(3.02 \pm 0.01 \mathrm{mg} / 100 \mathrm{~mL})$ than that extracted by high-speed centrifugal juice, which yielded $2.20 \pm$ $0.05 \mathrm{mg} / 100 \mathrm{~mL}$ of lycopene. Not to mention, the juice extracted using LSM was homogenous and the mixture was stable for several hours. This physical characteristic is favorable especially for production of commercial or home-made fruit juices. Total carotenoid content of fruit beverages was also shown to decline during storage at certain period of time. A study by Castro-López et al. [95] suggested that total carotenoid content of several fruit beverages decreased for $25 \%$ at the first 12 days of storage at 4,8 and $11^{\circ} \mathrm{C}$. Then, it continued to degrade for $50 \%$ until day 20 of storage. Oxidation was the main factor that caused the degradation. The presence of oxygen in the headspace of the container due to unproperly closed lid would induce great problem, thus, led to altered flavor characteristic and stabilty of the beverages [95]. However, consuming whole fruits would be a best choice because no processing is applied, therefore, the bioactive compound and functional properties of the fruits may would remain stable. To preserve the stability of juice, processing technique involving heat, electric field and pressure can also be applied. Those methods utilize physical treatment to suppress enzyme and microbial activity, therefore, leads to a more stable product. In consequences, carotenoids would be vulnerable to these methods. Pasteurization $\left(90^{\circ} \mathrm{C}\right.$ for $\left.30-60 \mathrm{~s}\right)$ were recommended to preserve nutritional value, including carotenoids, in tomato juice as reported by Odriozola-Serrano et al. [96]. However, since heat could alter carotenoids greatly, High Intensity Pulsed Electric Field (HIPEF) as non-thermal technique would be good alternative to preserve carotenoids as well as to maintain the stability of the juice. Concentration of carotenods in tomato juice treated with HIPEF at $35 \mathrm{kV} / \mathrm{cm}$ for $1500 \mu$ s with $4 \mu$ s bipolar pulses at $100 \mathrm{~Hz}$ was $14.7 \mathrm{mg} / 100 \mathrm{~mL} \mathrm{fw}$, which was slightly higher than that with pasteurization (14.4 $\mathrm{mg} / 100 \mathrm{~mL} \mathrm{fw})$ [96]. Moreover, study by Stinco et al. [97] reported that the application of High Pressure Processsing (HPP) can alter the level of carotenoids in carrot juice. Upon the treatment of HPP at 300 (one and three cycles), 450 (one cycle) and $600 \mathrm{MPa}$ (one cycle), total carotenoids in carrot juice decreased from $572.7 \mathrm{mg} / \mathrm{L}$ to $294.9-426 \mathrm{mg} / \mathrm{L}$. On the other hand, the shelf life of the juice could be extended to approximately 14 weeks upon HPP at 450 and $600 \mathrm{MPa}$ for $5 \mathrm{~min}$. In addition, the highest inactivity of polyphenol oxidases (57\%) and peroxidases (31\%) were minimum after HPP at 300 and $600 \mathrm{MPa}$, respectively. Thus, $\mathrm{HPP}$ at 600 and $3 \times 300 \mathrm{MPa}$ were suggested [97].

Processing animal-based foods while preserving the carotenoid content at the same time is posibble although high temperature heat is applied to make sure the ingredients are well cooked. In crustaceans and salmons, for instance, astaxanthin is present together with protein to which the pigments are attached, forming carotenoprotein complexes. The protein is denatured during heat exposure from cooking or frying, thus, the conformation complexes are compromised and astaxanthin is released, generating beautiful red-orange color. In this case, heat is needed to bring up the pigment [62]. In fact, increase in carotenoid concentration was observed in muscle of farmed rainbow trout during cooking. Hence, the color intensity of the fish which corresponded to carotenoid content was also enhanced. Lira et al. [98] also found that during cooking, heat did not have significant impact on carotenoid stability. To maintain the stability, however, storage under freezing is needed. The study on carotenoid stability in shrimps showed that during 45 days of storage in the freezer at $-17^{\circ} \mathrm{C}$, no significant loss was observed. Yet, the pigment degraded after 90 days of storage [98].

Fermentation, that has been practised for centuries, is recognised as processing method involving chemical changes by microorganisms which can also preserve the food material. In fermentation process, enzymes produced by microogranisms are able to mediate reaction leading to biosynthesis of diverse compounds, including carotenoids $[99,100]$. In association with carotenoids, several studies reported the determination of the pigment on fermented food. The changes of lutein and zeaxanthin in wheat bread by means of 12 strains of Lactic Acid Bacteria (LAB) was monitored by Antognoni et al. [101]. The strains were Lactobacillus (L.) fermentum (MR13), Lactobacillus rhamonosus (C249, C1272), Lactobacillus plantarum (LB102, LB124, LB126, LB245, 29DAN, 83DAN, 6BHI, 98A) and Lactobacillus brevis (3BHI). Result on carotenoid determination suggested that the use of $L$. fermentum MR13, L. plantarum LB102 and L. rhamnosus $\mathrm{C} 249$ did not give a significant change in carotenoids level. Moreover, L. plantarum strain LB124, LB126, LB245, 6BHI and 98A, L. rhamnosus $\mathrm{C} 1272$ and L. brevis $3 \mathrm{BHI}$ could not give a rise of the carotenoids level. Interestingly, when the dough was fermented by L. plantarum 29DAN and 83DAN, the concentration of zeaxanthin and lutein increased significantly [101]. The metabolism of several LAB strains could produce strong antioxidative compounds which can lead to increased bioacessibility of carotenoids. During the fermentation of orange juice, several identified carotenoids, i.e. neochrome and its isomer, karpoxanhin isomer, luteoxanthin, auroxanthin isomers, mutatoxanthin isomer, all-trans-zeaxanthin, all-trans-lutein, 9-, an 13-cis-lutein, $\beta$-cryptoxanthin, $\zeta$-carotene, all-trans- $\alpha$-carotene, and all-trans- $\beta$-carotene, ascended significantly, leading to elevated carotenoids level from 5.36 to $6.41 \mathrm{mg} / \mathrm{L}$ and $6.64 \mathrm{mg} / \mathrm{L}$ after 11 and 15 days of fermentation, reported by Escudero-López et al. [102].

In industrialised societies, the number of women having carrier in professional fields has also been grown. Breastfeeding mothers who spend most of the their time in offices depend on breast pump and proper storage to keep their breastmilk prior to breastfeeding the infants. Thus, breast milk handling should also be addressed well to preserve the healthy nutrients inside. Tacken et al. [103] studied the effect of storage and microwave heating on the carotenoid content ( $\alpha$-carotene, $\beta$-carotene, lycopene and lutein) in breast milk. Breast milk was stored in refrigerator at $4^{\circ} \mathrm{C}$ for $48 \mathrm{~h}$ and freezer at $-18^{\circ} \mathrm{C}$ for 28 days. Moreover, heating process was conducted by means of microwave with low frequency pulse stream $(90 \mathrm{~W}$, $\left.5-30 \mathrm{~s}, 35-40^{\circ} \mathrm{C}\right)$. Result suggested that storage in refrigerator and freezer did not decrease the level of $\alpha$-carotene, $\beta$-carotene and lycopene. As for heating process, the author recommended to perform microwave heating with low energy since no decrease was observed towards $\alpha$-carotene, $\beta$-carotene and lycopene. However, lutein content was compromised during storage-both in refrigerator and freezer-and microwave heating [103]. Another studies by 
Table 2 Bioavailability of carotenoids in selected food sources

\begin{tabular}{|c|c|c|c|c|c|}
\hline Carotenoids & Source & Sample treatment & Determination method & Bioavailability (\%) & References \\
\hline$\alpha$-Carotene & Carrot & Fresh & $\begin{array}{l}\text { Simulated human gastric and pancreatic digestion } \\
\text { using pepsin solution and bile/pancreatin solution }\end{array}$ & \pm 30 & [107] \\
\hline \multirow[t]{7}{*}{$\beta$-Carotene } & \multirow[t]{2}{*}{ Broccoli } & $\begin{array}{l}\text { Microwave-prepared } \\
\text { (5 min), blended with } \\
\text { kitchen blender }(1 \mathrm{~min})\end{array}$ & $\begin{array}{l}\text { In vitro digestion by means of saliva solution, } \\
\text { mucin, bovine serum albumin, pepsin from } \\
\text { porcine stomach, dudodenal juice, bile solution, } \\
\text { human pancreatic lipase, colipase, cholesterol } \\
\text { esterase, phospholipase, and taurocholate salts }\end{array}$ & $77-81$ & [108] \\
\hline & & Fresh & $\begin{array}{l}\text { Simulated human gastric and pancreatic digestion } \\
\text { using pepsin solution and bile/pancreatin solution }\end{array}$ & 6 & [107] \\
\hline & \multirow[t]{3}{*}{ Carrot } & Fresh & $\begin{array}{l}\text { Simulated human gastric and pancreatic digestion } \\
\text { using pepsin solution and bile/pancreatin solution }\end{array}$ & \pm 30 & [107] \\
\hline & & Raw & $\begin{array}{l}\text { Plasma sample determination from eight volunteers } \\
\text { aged } 38-75 \text { years old }\end{array}$ & 41.4 & [109] \\
\hline & & Cooked & $\begin{array}{l}\text { Plasma sample determination from eight volunteers } \\
\text { aged } 38-75 \text { years old }\end{array}$ & 65.1 & [109] \\
\hline & Garri & $\begin{array}{l}\text { Fermented ( } 1 \text { day) and } \\
\text { roasted }\left(80 \text { and } 120^{\circ} \mathrm{C}\right)\end{array}$ & $\begin{array}{l}\text { In vivo determination by means of plasma samples } \\
\text { from Wistar rats }\end{array}$ & $8.5-17.4$ & [110] \\
\hline & Melons & Fresh & $\begin{array}{l}\text { In vitro digestion with pepsin, porcine pancreatic } \\
\text { lipase, pancreatin and bile extract, continued to } \\
\text { determination using Caco- } 2 \text { cells }\end{array}$ & 11.6 & [111] \\
\hline Lycopene & Tomato & Tomato sauce & $\begin{array}{l}\text { Plasma sample analysis } 12 \text { healthy, non-pregnant, } \\
\text { non-smoking subjects (six male, } 12 \text { female, } \\
\text { 19-43 years old) }\end{array}$ & $3.19-4.97$ & [112] \\
\hline \multirow[t]{3}{*}{$\beta$-Cryptoxanthin } & $\begin{array}{l}\text { Milk-based } \\
\text { fruit drinks }\end{array}$ & $\begin{array}{l}\text { Enriched with } 75 \mu \mathrm{g} / 250 \mathrm{~mL} \\
\text { of } \beta \text {-cryptoxanthin }\end{array}$ & $\begin{array}{l}\text { In vitro digestion using saliva solution, } \alpha \text {-amylase, } \\
\text { gastric juice, mucin, bovine serum albumin, pepsin } \\
\text { from porcine stomach, duodenal juice, bile solution, } \\
\text { human pancreatic lipase, colipase, cholesterol } \\
\text { esterase phospholipase A2 and taurocholate salts }\end{array}$ & $83-84$ & [113] \\
\hline & \multirow[t]{2}{*}{ Orange } & Fresh & $\begin{array}{l}\text { In vitro digestion using artificial salva solution and } \\
\text { porcine bile extract/pancreatin solution }\end{array}$ & 4.9 & {$[114]$} \\
\hline & & Juice & $\begin{array}{l}\text { In vitro digestion using artificial salva solution and } \\
\text { porcine bile extract/pancreatin solution }\end{array}$ & 25.9 & {$[114]$} \\
\hline \multirow[t]{4}{*}{ Lutein } & Bean & Fresh & $\begin{array}{l}\text { Simulated human gastric and pancreatic digestion } \\
\text { using pepsin solution and bile/pancreatin solution }\end{array}$ & $<14$ & [107] \\
\hline & \multirow[t]{2}{*}{ Broccoli } & $\begin{array}{l}\text { Microwave-prepared } \\
\text { (5 min), blended with } \\
\text { kitchen blender }(1 \mathrm{~min})\end{array}$ & $\begin{array}{l}\text { In vitro digestion by means of saliva solution, mucin, } \\
\text { bovine serum albumin, pepsin from porcine } \\
\text { stomach, dudodenal juice, bile solution, human } \\
\text { pancreatic lipase, colipase, cholesterol esterase, } \\
\text { phospholipase, and taurocholate salts }\end{array}$ & $88-95$ & [108] \\
\hline & & Fresh & $\begin{array}{l}\text { Simulated human gastric and pancreatic digestion } \\
\text { using pepsin solution and bile/pancreatin solution }\end{array}$ & 6 & {$[107]$} \\
\hline & Milk & $\begin{array}{l}\text { Fermented, fortified with } \\
\text { lutein }(4 \text { and } 8 \mathrm{mg} / 100 \mathrm{~mL})\end{array}$ & $\begin{array}{l}\text { In vivo determination using blood sample analysis } \\
\text { from healthy volunteers ( } 12 \text { men and } 12 \text { women) }\end{array}$ & $2.14-2.48$ & [115] \\
\hline
\end{tabular}

Buss et al. [104] and Hanna et al. [105] mentioned that antioxidant activity and vitamin $\mathrm{C}$ in the breastmilk may decreased even during low temperature storage after several days. Hence, although most carotenoids did not significantly decrease during low temperature storage, feeding infants with breastmilk not too long after it is produced is recommended.

Carotenoids should be released from food material in order to bring up their biological functions. Despite of the posibility of carotenoid degradation, food processing is one of efforts to enhance bioavailability so that the absorption of carotenoid in human body can be maximized. Table 2 lists the bioavailability (in percentage) of some well-known carotenoids from several food sources. Moreover, several strategies to improve bioavailability of carotenoids can be performed, i.e. modification of food processing technology, providing food preparation advice and nutritional recommendations (e.g. to consume carotenoids with lipids), and creating protection formula to improve the absorption (e.g. via nanoencapsulation) [106].

\section{CONCLUSION}

The indication of oxidative stress in pregnancy can be manifested in several events such as GDM, pre-eclampsia, IUGR at which the administration of carotenoids may reduce the occurrence. Carotenoids also help to improve visual and cognitive function during the growth and development of infants and children. As carotenoids are abundantly found in natural ingredients, people can utilize them to fulfill the needs of micronutrients in order to improve health function especially during pregnancy, in infants and children. Food processing to preserve the content of carotenoids in food ingredients should be well-acknowledged to 
minimize the odds of degradation, thus, people can obtain the good function of the pigment through their daily consumption.

\section{CONFLICTS OF INTEREST}

The authors declare they have no conflicts of interest.

\section{AUTHORS' CONTRIBUTION}

MNUP designed the concept, wrote and revised the manuscript. RDC and DML contributed to correct the manuscript.

\section{REFERENCES}

[1] Jiang X, Dong M, He Y, Shen J, Jing W, Yang N, et al. Research on the design of and preference for collection modes of reusable takeaway containers to promote sustainable consumption. Int J Environ Res Public Health 2020;17:4764.

[2] Liu C, Chen J. Consuming takeaway food: convenience, waste and Chinese young people's urban lifestyle. J Consumer Cult 2019.

[3] Chenzi Technology. The analysis report on big data of Chinese catering take-out in 2018. Chenzi Technology, Dalian, 2019.

[4] Lipoeto NI, Lin KG, Angeles-Agdeppa I. Food consumption patterns and nutrition transition in South-East Asia. Public Health Nutr 2013;16:1637-43.

[5] Blum LS, Mellisa A, Sari EK, Yusadiredja IN, van Liere M, Shulman S, et al. In-depth assessment of snacking behaviour in unmarried adolescent girls 16-19 years of age living in urban centres of Java, Indonesia. Matern Child Nutr 2019;15:e12833.

[6] Green M, Hadihardjono DN, Pries AM, Izwardy D, Zehner E, Huffman SL. High proportions of children under 3 years of age consume commercially produced snack foods and sugarsweetened beverages in Bandung City, Indonesia. Matern Child Nutr 2019;15:e12764.

[7] Swaminathan S, Edward BS, Kurpad AV. Micronutrient deficiency and cognitive and physical performance in Indian children. Eur J Clin Nutr 2013;67:467-74.

[8] Bailey RL, West KP, Black RE. The epidemiology of global micronutrient deficiencies. Ann Nutr Metab 2015;66:22-33.

[9] Britton G. Structure and properties of carotenoids in relation to function. FASEB J 1995;9:1551-8.

[10] Maoka T. Carotenoids as natural functional pigments. J Nat Med 2020;74:1-16.

[11] de Lira LQ, Dimenstein R. Vitamin A and gestational diabetes. Rev Assoc Med Bras 2010;56:355-9.

[12] Sommer A, Vyas KS. A global clinical view on vitamin A and carotenoids. Am J Clin Nutr 2012;96:1204S-6S.

[13] Cheng J, Miller B, Balbuena E, Eroglu A. Lycopene protects against smoking-induced lung cancer by inducing base excision repair. Antioxidants (Basel) 2020;9:643.

[14] Gong X, Draper CS, Allison GS, Marisiddaiah R, Rubin LP. Effects of the macular carotenoid lutein in human retinal pigment epithelial cells. Antioxidants (Basel) 2017;6:100.

[15] Osganian SK, Stampfer MJ, Rimm E, Spiegelman D, Manson JE, Willett WC. Dietary carotenoids and risk of coronary artery disease in women. Am J Clin Nutr 2003;77:1390-9.
[16] Li W, Hellsten A, Jacobsson LS, Blomqvist HM, Olsson AG, Yuan XM. Alpha-tocopherol and astaxanthin decrease macrophage infiltration, apoptosis and vulnerability in atheroma of hyperlipidaemic rabbits. J Mol Cell Cardiol 2004;37:969-78.

[17] Arscott SA, Tanumihardjo SA. Carrots of many colors provide basic nutrition and bioavailable phytochemicals acting as a functional food. Comp Rev Food Sci Food Saf 2010;9:223-39.

[18] Young AJ, Lowe GL. Carotenoids-antioxidant properties. Antioxidants (Basel) 2018;7:28.

[19] Edge R, Truscott TG. Singlet oxygen and free radical reactions of retinoids and carotenoids - a review. Antioxidants (Basel) 2018;7:5.

[20] Gayer J, Smith G. Micronutrient fortification of food in Southeast Asia: recommendations from an expert workshop. Nutrients 2015;7:646-58.

[21] Yeh EB, Barbano DM, Drake M. Vitamin fortification of fluid milk. J Food Sci 2017;82:856-64.

[22] Burton GJ, Jauniaux E. What is the placenta?. Am J Obstet Gynecol 2015;213:S6.e1-S6.e4.

[23] Pereira AC, Martel F. Oxidative stress in pregnancy and fertility pathologies. Cell Biol Toxicol 2014;30:301-12.

[24] Tuuli MG, Longtine MS, Nelson DM. Review: oxygen and trophoblast biology - a source of controversy. Placenta 2011;32: S109-S18.

[25] Agarwal A, Aponte-Mellado A, Premkumar BJ, Shaman A, Gupta $\mathrm{S}$. The effects of oxidative stress on female reproduction: a review. Reprod Biol Endocrinol 2012;10:49.

[26] Zielińska MA, Wesołowska A, Pawlus B, Hamułka J. Health effects of carotenoids during pregnancy and lactation. Nutrients $2017 ; 9: 838$

[27] Klingler M, Demmelmair H, Larque E, Koletzko B. Analysis of FA contents in individual lipid fractions from human placental tissue. Lipids 2003;38:561-6.

[28] Carr DB, Gabbe S. Gestational diabetes: detection, management, and implications. Clin Diabetes 1998;16:4-11.

[29] Mumtaz M. Gestational diabetes mellitus. Malays J Med Sci 2000;7:4-9.

[30] Nguyen CL, Pham NM, Binns CW, Duong DV, Lee AH. Prevalence of gestational diabetes mellitus in Eastern and Southern Asia: a systematic review and meta-analysis. J Diabetes Res 2018;2018:6536974.

[31] Lorenzoni F, Giampietri M, Ferri G, Lunardi S, Madrigali V, Battini L, et al. Lutein administration to pregnant women with gestational diabetes mellitus is associated to a decrease of oxidative stress in newborns. Gynecol Endocrinol 2013;29:901-3.

[32] Kramer MS, Kahn SR, Platt RW, Genest J, Rozen R, Chen MF, et al. Antioxidant vitamins, long-chain fatty acids, and spontaneous preterm birth. Epidemiology 2009;20:707-13.

[33] Carmichael SL, Yang W, Shaw GM; National Birth Defects Prevention Study. Maternal dietary nutrient intake and risk of preterm delivery. Am J Perinatol 2013;30:579-88.

[34] Khachik F, Spangler CJ, Smith JC, Canfield LM, Steck A, Pfander $\mathrm{H}$. Identification, quantification, and relative concentrations of carotenoids and their metabolites in human milk and serum. Anal Chem 1997;69:1873-81.

[35] Vishwanathan R, Kuchan MJ, Sen S, Johnson EJ. Lutein and preterm infants with decreased concentrations of brain carotenoids. J Pediatr Gastr Nutr 2014;59:659-65.

[36] Sharma JB, Kumar A, Kumar A, Malhotra M, Arora R, Prasad S, et al. Effect of lycopene on pre-eclampsia and intra-uterine 
growth retardation in primigravidas. Int J Gynaecol Obstet 2003;81:257-62.

[37] Setyawati A, Widiasih R, Ermiati E. Faktor-faktor yang berhubungan dengan kejadian preeklampsia di Indonesia. Jurnal Perawat Indonesia 2018;2:32-40.

[38] Cohen JM, Kahn SR, Platt RW, Basso O, Evans RW, Kramer MS. Small-for-gestational-age birth and maternal plasma antioxidant levels in mid-gestation: a nested case-control study. BJOG 2015;122:1313-21.

[39] Henriksen BS, Chan G, Hoffman RO, Sharifzadeh M, Ermakov IV, Gellermann W, et al. Interrelationships between maternal carotenoid status and newborn infant macular pigment optical density and carotenoid status. Invest Ophth Vis Sci 2013; 54:5568-78.

[40] Bone RA, Landrum JT, Fernandez L, Tarsis SL. Analysis of the macular pigment by HPLC: retinal distribution and age study. Invest Ophthalmol Vis Sci 1988;29:843-9.

[41] Bone RA, Landrum JT, Hime GW, Cains A, Zamor J. Stereochemistry of the human macular carotenoids. Invest Ophthalmol Vis Sci 1993;34:2033-40.

[42] Bone RA, Landrum JT, Friedes LH, Gomez CM, Kilburn MD, Menendez E, et al. Distribution of lutein and zeaxanthin stereoisomers in the human retina. Exp Eye Res 1997;64:211-18.

[43] Zimmer JP, Hammond BR. Possible influences of lutein and zeaxanthin on the developing retina. Clin Ophthalmol 2007;1: 25-35.

[44] Liew SHM, Gilbert CE, Spector TD, Mellerio J, Van Kujik FJ, Beatty S, et al. Central retinal thickness is positively correlated with macular pigment optical density. Exp Eye Res 2006;82: 915-20.

[45] Hammond BR. Possible role for dietary lutein and zeaxanthin in visual development. Nutr Rev 2008;66:695-702.

[46] O'Hagan JB, Khazova M, Proce LLA. Low-energy light bulbs, computers, tablets and the blue light hazard. Eye 2016;30:230-3.

[47] Long AC, Kuchan M, Mackey AD. Lutein as an ingredient in pediatric nutritionals. J AOAC Int 2019;102:1034-43.

[48] Chan C, Leung I, Lam KW, Tso MO. The occurrence of retinol and carotenoids in human subretinal fluid. Curr Eye Res 1998;17:890-5.

[49] Kanan Y, Moiseyev G, Agarwal N, Ma JX, Al-Ubaidi MR. Light induces programmed cell death by activating multiple independent proteases in a cone photoreceptor cell line. Invest Ophth Vis Sci 2007;48:40-51.

[50] Johra FT, Bepari AK, Bristy AT, Reza HM. A mechanistic review of $\beta$-carotene, lutein, and zeaxanthin in eye health and disease. Antioxidants (Basel) 2020;9:1046.

[51] Rasmussen HM, Johnson EJ. Nutrients for the aging eye. Clin Interv Aging 2013;8:741-8.

[52] Age-Related Eye Disease Study Research Group. A randomized, placebo-controlled, clinical trial of high-dose supplementation with vitamins $\mathrm{C}$ and $\mathrm{E}$, beta carotene, and zinc for age-related macular degeneration and vision loss: AREDS report no. 8. Arch Ophthalmol 2001;119:1417-36.

[53] Liu Z, Neuringer M, Erdman JW, Kuchan MJ, Renner L, Johnson $\mathrm{EE}$, et al. The effects of breastfeeding versus formula-feeding on cerebral cortex maturation in infant rhesus macaques. Neuroimage 2019;184:372-85.

[54] Giordano E, Quadro L. Lutein, zeaxanthin and mammalian development: metabolism, functions and implications for health. Arch Biochem Biophys 2018;647:33-40.
[55] Jeon S, Neuringer M, Johnson EE, Kuchan MJ, Pereira SL, Johnson EJ, et al. Effect of carotenoid supplemented formula on carotenoid bioaccumulation in tissues of infant rhesus macaques: a pilot study focused on lutein. Nutrients 2017;9:51.

[56] Saint SE, Renzi-Hammond LM, Khan NA, Hilman CH, Frick JE, Hammond BR. The macular carotenoids are associated with cognitive function in preadolescent children. Nutrients 2018; 10:193.

[57] Vishwanathan R, Neuringer M, Snodderly DM, Schalch W, Johnson EJ. Macular lutein and zeaxanthin are related to brain lutein and zeaxanthin in primates. Nutr Neurosci 2013;16:21-9.

[58] Ickowitz A, Rowland D, Powell B, Salim MA, Sunderland T. Forests, trees, and micronutrient-rich food consumption in Indonesia. PLoS One 2016;11:e0154139.

[59] Kaneko JJ. Carbohydrate metabolism and its diseases. In: Kaneko JJ, Harvey JW, Bruss ML, editors. Clinical biochemsitry of domestic animals. 5th ed. Cambridge: Academic Press/ Elsevier; 1997, pp. 45-81.

[60] Lonnie M, Hooker E, Brunstrom JM, Corfe BM, Green MA, Watson AW, et al. Protein for life: review of optimal protein intake, sustainable dietary sources and the effect on appetite in ageing adults. Nutrients 2018;10:360.

[61] Williamson CS. Nutrition in pregnancy. Nutr Bull 2006;31:28-59.

[62] Langi P, Kiokias S, Varzakas T, Proestos C. Carotenoids: from plants to food and feed industries. In: Barreiro C, Barredo JL, editors. Microbial Carotenoids. Methods in Molecular Biology. New York, NY: Humana Press/Springer Nature; 2018, pp. 57-71.

[63] Xue Y, Campos-Giménez E, Redeuil KM, Lévèques A, ActisGoretta L, Vinyes-Pares G, et al. Concentrations of carotenoids and tocopherols in breast milk from urban Chinese mothers and their associations with maternal characteristics: a cross-sectional study. Nutrients 2017;9:1229.

[64] Charoensiri R, Kongkachuichai R, Suknicom S, Sungpuag P. Beta-carotene, lycopene, and alpha-tocopherol contents of selected Thai fruits. Food Chem 2009;113:202-7.

[65] Setiawan B, Sulaeman A, Giraud DW, Driskell JA. Carotenoid content of selected Indonesian fruits. J Food Compos Anal 2001;14:169-76

[66] Yano M, Kato M, Ikoma Y, Kawasaki A, Fukuzawa Y, Sugiura M, et al. Quantitation of carotenoids in raw and processed fruits in Japan. Food Sci Technol Res 2005;11:13-18.

[67] Delgado-Pelayo R, Gallardo-Guerrero L, Hornero-Méndez D. Chlorophyll and carotenoid pigments in the peel and flesh of commercial apple fruit varieties. Food Res Int 2014;65:272-81.

[68] Heng Z, Sheng O, Yan S, Lu H, Motorykin I, Gao H, et al. Carotenoid profiling in the peel and pulp of 36 selected Musa varieties. Food Sci Technol Res 2017;23:603-11.

[69] Holden JM, Eldridge AL, Beecher GR, Marilyn Buzzard I, Bhagwat S, Davis CS, et al. Carotenoid content of U.S. foods: an update of the database. J Food Compos Anal 1999;12:169-96.

[70] Bramley PM. Is lycopene beneficial to human health? Phytochemistry 2000;54:233-6.

[71] Stinco CM, Benítez-González AM, Hermanz D, Vicario IM, Meléndez-Martínez AJ. Development and validation of a rapid resolution liquid chromatography method for the screening of dietary plant isoprenoids: carotenoids, tocopherols and chlorophylls. J Chromatogr A 2014;1370:162-70.

[72] Tee ES, Lim CL. Carotenoid composition and content of Malaysian vegetables and fruits by the AOAC and HPLC methods. Food Chem 1991;41:309-39. 
[73] Hulshof PJM, Xu C, van de Bovenkamp P, Muhilal, West CE. Application of a validated method for the determination of provitamin A carotenoids in Indonesian foods of different maturity and origin. J Agric Food Chem 1997;45:1174-9.

[74] Lako J, Trenerry VC, Wahlqvist M, Wattanapenpaiboon N, Sotheeswaran S, Premier R. Phytochemical flavonols, carotenoids and the antioxidant properties of a wide selection of Fijian fruit, vegetables and other readily available foods. Food Chem 2007;101:1727-41.

[75] Zhou C, Zhao D, Sheng Y, Tao J, Yang Y. Carotenoids in fruits of different persimmon cultivars. Molecule 2011;16:624-36.

[76] Liu C, Zhang H, Dai Z, Liu X, Liu Y, Deng X, et al. Volatile chemical and carotenoid profiles in watermelons [Citrullus vulgaris (Thunb.) Schrad (Cucurbitaceae)] with different flesh colors. Food Sci Biotechnol 2012;21:531-41.

[77] dos Reis LCR, de Oliveira VR, Hagen MEK, Jablonski A, Flôres $\mathrm{SH}$, de Oliveira Rios A. Effect of cooking on the concentration of bioactive compounds in broccoli (Brassica oleracea var. Avenger) and cauliflower (Brassica oleracea var. Alphina F1) grown in an organic system. Food Chem 2015;172:770-7.

[78] Aruna G, Mamatha BS, Baskaran V. Lutein content of selected Indian vegetables and vegetable oils determined by HPLC. J Food Compos Anal 2009;22:632-6.

[79] Lakshminarayana R, Raju M, Krishnakantha TP, Baskaran V. Determination of major carotenoids in a few Indian leafy vegetables by high-performance liquid chromatography. J Agric Food Chem 2005;53:2838-42.

[80] Schweiggert U, Kurz C, Schieber A, Carle R. Effects of processing and storage on the stability of free and esterified carotenoids of red peppers (Capsicum annum L.) and hot chilli peppers (Capsicum frutescens L.). Eur Food Res Technol 2007;225:261-70.

[81] Rodriguez-Amaya DB. Carotenoids and food preparation - the retention of provitamin A carotenoids in prepared, processed, and stored foods. Rio de Janeiro: John Snow Inc.; 1997.

[82] Bacchetti T, Masciangelo S, Micheletti A, Ferretti G. Carotenoids, phenolic compounds and antioxidant capacity of five local Italian corn (Zea mays L.) kernels. J Nutr Food Sci 2013;3:1000237.

[83] Mamatha BS, Arunkumar R, Baskaran V. Effect of processing on major carotenoid levels in corn (Zea mays) and selected vegetables: bioavailability of lutein and zeaxanthin from processed corn in mice. Food Bioprocess Technol 2012;5:1355-63.

[84] Saraswati P, Soplanit A, Syahputra AT, Kossay L, Muid N, Ginting E, et al. Yield trial and sensory evaluation of sweetpotato cultivars in Highland Papua and West Papua Indonesia. J Trop Agric 2013;51:74-83.

[85] Karadas F, Grammenidis E, Surai PF, Acamovic T, Sparks NHC. Effects of carotenoids from lucerne, marigold and tomato on egg yolk pigmentation and carotenoid composition. Brit Poultry Sci 2006;47:561-6.

[86] Tang G, Qin J, Dolnikowski GG, Russel RM, Grusak MA. Golden rice is an effective source of vitamin A. Am J Clin Nutr 2009;89:1776-83.

[87] Baker RTM, Pfeiffer AM, Schöner FJ, Smith-Lemmon L. Pigmenting efficacy of astaxanthin and canthaxanthin in freshwater reared Atlantic salmon, Salmo salar. Anim Feed Sci Technol 2002;99:97-106.

[88] Pan CH, Chien YH. Concentration and composition of astaxanthin in black tiger prawn Penaeus monodon postlarvae fed Artemia sp. Nauplii or mauxia shrimsp Acetes intermedius. J World Aquacult Soc 2003;34:57-65.
[89] Niu J, Li CH, Liu YJ, Tian LX, Chen X, Huang Z, et al. Dietary values of astaxanthin and canthaxanthin in Penaeus monodon in the presence and absence of cholesterol supplementation: effect on growth, nutrient digestibility and tissue carotenoid composition. Br J Nutr 2012;108:80-91.

[90] Nzamwita M, Duodu KG, Minnaar A. Stability of $\beta$-carotene during baking of orange-fleshed sweet potato-wheat composite bread and estimated contribution to vitamin A requirements. Food Chem 2017;228:85-90.

[91] Paznocht L, Kotíková Z, Orsák M, Lachman J, Martinek P. Carotenoid changes of colored-grain wheat flours during bun-making. Food Chem 2019;277:725-34.

[92] Kao FJ, Chiu YS, Tsou MJ, Chiang WD. Effects of Chinese domestic cooking methods on the carotenoid composition of vegetables in Taiwan. LWT - Food Sci Technol 2012;46: 485-92.

[93] Pyo YH, Jin YJ, Hwang JY. Comparison of the effects of blending and juicing on the phytochemicals contents and antioxidant capacity of typical Korean kernel fruit juices. Prev Nutr Food Sci 2014;19:108-14.

[94] Kim MJ, Kim JI, Kang MJ, Kwon B, Jun JG, Choi JH, et al. Quality evaluation of fresh tomato juices prepared using highspeed centrifugal and low-speed masticating household juicers. Food Sci Biotechnol 2015;24:61-6.

[95] Castro-López C, Sánchez-Alejo EJ, Saucedo-Pompa S, Rojas R, Aranda-Ruiz J, Martínez-Avila GCG. Fluctuations in phenolic content, ascorbic acid and total carotenoids and antioxidant activity of fruit beverages during storage. Heliyon 2016;2:e0152.

[96] Odriozola-Serrano I, Soliva-Fortuny R, Hernández-Jover T, Martín-Belloso O. Carotenoid and phenolic profile of tomato juices processed by high intensity pulsed electric fields compared with conventional thermal treatments. Food Chem 2009;112:258-66.

[97] Stinco CM, Szczepańska J, Marszałek K, Pinto CA, Inácio RS, Mapelli-Brahm P, et al. Effect of high-pressure processing on carotenoids profile, colour, microbial and enzymatic stability of cloudy carrot juice. Food Chem 2019;299:125112.

[98] Lira GM, Lopez AMQ, Firmino GO, Santos SD, de Souza Bezerra R. Total carotenoids and antioxidant activity of fillets and shells (in natura or cooked) of "Vila Franca" shrimp (Litopenaeus schmitti) in different intervals of storage under freezing. Cienc Agrotec 2017;41:94-103.

[99] Saranraj P, Sivasakthivelan P, Naveen M. Fermentation of fruit wine and its quality analysis: a review. Aust J Sci Technol 2017;1:85-97.

[100] Mapelli-Brahm P, Barba FJ, Remize F, Garcia C, Fessard A, Khaneghah AM, et al. The impact of fermentation processes on the production, retention and bioavailability of carotenoids: an overview. Trends Food Sci Technol 2020;99:389-401.

[101] Antognoni F, Mandrioli R, Potente G, Saa DLT, Gianotti A. Changes in carotenoids, phenolic acids and antioxidant capacity in bread wheat doughs fermented with different lactic acid bacteria strains. Food Chem 2019;292:211-16.

[102] Escudero-López B, Cerrillo I, Herrero-Martín G, HorneroMéndez D, Gil-Izquiredo A, Medina S, et al. Fermented orange juice: source of higher carotenoid and flavanone contents. J Agric Food Chem 2013;61:8773-82.

[103] Tacken KJM, Vogelsang A, van Lingen RA, Slootstra J, Dikkeschei BD, van Zoeren-Grobben D. Loss of triglycerides 
and carotenoids in human milk after processing. Arch Dis Child Fetal Neonatal Ed 2009;94:F447-F50.

[104] Buss IH, McGill F, Darlow BA, Winterbourn CC. Vitamin C is reduced in human milk after storage. Acta Paediater 2001; 90:813-15.

[105] Hanna N, Ahmed K, Anwar M, Petrova A, Hiatt M, Hegyi T. Effect of storage on breast milk antioxidant activity. Arch Dis Child Fetal Neonatal Ed 2004;89:F518-F20.

[106] Desmarchelier C, Borel P. Overview of carotenoid bioavailability determinants: from dietary factors to host genetic variations. Trend Food Sci Technol 2017;69:270-80.

[107] McInerney JK, Seccafien CA, Stewart CM, Bird AR. Effects of high pressure processing on antioxidant activity, and total carotenoid content and availability, in vegetables. Innov Food Sci Emerg Technol 2007;8:543-8.

[108] Granado F, Olmedilla B, Herrero C, Pérez-Sacristán B, Blanco I, Blázquez S. Bioavailability of carotenoids and tocopherols from broccoli: in vivo and in vitro assessment. Exp Biol Med (Maywood) 2006;231:1733-8.

[109] Livny O, Reifen R, Levy I, Madar Z, Faulks R, Southon S, et al. $\beta$-carotene bioavailability from differently processed carrot meals in human ileostomy volunteers. Eur J Nutr 2003;42:338-45.

[110] Phorbee OO, Olayiwola IO, Sanni SA. Bioavailability of beta carotene in traditional fermented, roasted granules, gari from bio-fortified cassava roots. Food Nutr Sci 2013;4: 1247-54.

[111] Fleshman MK, Lester GE, Riedl KM, Kopec RE, Narayanasamy S, Curly RW, et al. Carotene and novel apocarotenoid concentrations in orange-fleshed Cucumis melo Melons: determinations of $\beta$-carotene bioaccessibility and bioavailability. J Agric Food Chem 2011;59:4448-54.

[112] Unlu NZ, Bohn T, Francis DM, Nagaraja HN, Clinton SK, Schwartz SJ. Lycopene from heat-induced cis-isomer-rich tomato sauce is more bioavailable than from all-trans-rich tomato sauce in human subjects. Br J Nutr 2007;98:140-6.

[113] Granado-Lorencio F, Donoso-Navarro E, Sánchez-Siles LM, Blanco-Navarro I, Pérez-Sacristán B. Bioavailability of $\beta$-cryptoxanthin in the presence of phytosterols: in vitro and in vivo studies. J Agric Food Chem 2011;59:11819-24.

[114] Aschoff JK, Rolke CL, Breusing N, Bosy-Westphal A, Högel J, Carle $\mathrm{R}$, et al. Bioavailability of $\beta$-cryptoxanthin is greater from pasteurized orange juice than from fresh oranges - a randomized cross-over study. Mol Nutr Food Res 2015;59: 1896-904.

[115] Granado-Lorencio F, Herrero-Barbudo C, Olmedilla-Alonso B, Blanco-Navarro I, Pérez-Sacristán B. Lutein bioavailability from lutein ester-fortified fermented milk: in vivo and in vitro study. J Nutr Biochem 2010;21:133-9. 